\title{
Anti-apoptotic potential of several antidiabetic medicinal plants of the eastern James Bay Cree pharmacopeia in cultured kidney cells
}

Shilin Li ${ }^{1,2}$, Sarah Pasquin ${ }^{1}$, Hoda M. Eid ${ }^{1,2,3}$, Jean-François Gauchat ${ }^{1}$, Ammar Saleem $^{4}$ and Pierre S. Haddad ${ }^{1,2^{*}}$

\begin{abstract}
Background: Our team has identified 17 Boreal forest species from the traditional pharmacopeia of the Eastern James Bay Cree that presented promising in vitro and in vivo biological activities in the context of type 2 diabetes (T2D). We now screened the 17 plants extracts for potential anti-apoptotic activity in cultured kidney cells and investigated the underlying mechanisms.

Methods: MDCK (Madin-Darnby Canine Kidney) cell damage was induced by hypertonic medium (700 mOsm/L) in the presence or absence of maximal nontoxic concentrations of each of the 17 plant extracts. After $18 \mathrm{~h}$ ' treatment, cells were stained with Annexin V (AnnV) and Propidium iodide (PI) and subjected to flow cytometry to assess the cytoprotective $\left(\mathrm{AnnV}^{-} / \mathrm{PI}^{-}\right)$and anti-apoptotic $\left(\mathrm{AnnV}^{+} / \mathrm{PI}^{-}\right)$potential of the 17 plant extracts. We then selected a representative subset of species (most cytoprotective, moderately so or neutral) to measure the activity of caspases 3,8 and 9 .

Results: Gaultheria hispidula and Abies balsamea are amongst the most powerful cytoprotective and anti-apoptotic plants and appear to exert their modulatory effect primarily by inhibiting caspase 9 in the mitochondrial apoptotic signaling pathway.

Conclusion: We conclude that several Cree antidiabetic plants exert anti-apoptotic activity that may be relevant in the context of diabetic nephropathy (DN) that affects a significant proportion of Cree diabetics.
\end{abstract}

Keywords: Aboriginal traditional medicine, Diabetic nephropathy, MDCK cells, Annexin V, Propidium iodide, Caspase

\section{Background}

Diabetes mellitus (DM), first officially recorded in ancient Egypt, was initially considered as a rare condition in which patient urinated excessively and lost weight [1]. Clinically, DM refers to a group of metabolic diseases in which there is a chronic hyperglycemic condition as a result of defects in insulin secretion, insulin action or both $[2,3]$. Due to compromised insulin secretion or sensitivity, postprandial metabolism is disturbed, resulting in less

\footnotetext{
* Correspondence: pierre.haddad@umontreal.ca

'Department of Pharmacology and Physiology, Université de Montréal, P.O. Box 6128, Downtown Postal Station, Montreal, (Quebec) H3C 3J7, Canada ${ }^{2}$ Natural Health Products and Metabolic Diseases Laboratory, CIHR Team in Aboriginal Antidiabetic Medicines and Montreal Diabetes Research Center, CRCHUM, Montreal, Canada

Full list of author information is available at the end of the article
}

efficient uptake and utilization of glucose by the targeted tissues, further leading to elevated blood glucose level, more utilization of proteins and fats [4].

The prevalence of DM is rapidly increasing worldwide as a result of sedentary lifestyle, obesity, ageing, smoking, high blood pressure, genetic predisposition, psychiatric disorder such as depression and so on [5]. DM is predicted to affect 366 million individuals by the year 2030 [5-8]. Notably, Aboriginal populations worldwide are disproportionally affected by T2D. This has been linked to rapid environmental changes and to potential genetic predisposition to higher conservation of food calories [9-13]. For instance, the age-adjusted prevalence of T2D in the Cree populations of Eeyou Istchee (CEI - Eastern James Bay area of Quebec, Canada) averaged 29\% in 2009 
$[11,14]$. Cree communities also suffer from higher prevalence of diabetic complications, notably DN. This is due at least in part to the cultural inappropriateness of modern drug treatments $[15,16]$.

In western countries, end-stage renal disease (ESRD) is mainly caused by DN [17]. Development of proteinuria, considered as the key feature of $\mathrm{DN}$, is related to the decline of glomerular filtration rate (GFR), eventually leading to a progressive loss of renal function [18]. Hypertension and poor glycaemic control are usually associated with DN $[19,20]$. More importantly and according to numerous recent studies, it is well established that renal tubular cell apoptosis contributes to the development of DN, leading to gradual loss of renal mass [21-23]. In this context, different cell models can be used to study renal cell apoptosis, such as MDCK cells subjected to hypertonic stress [24].

The Canadian Institutes of Health Research Team in Aboriginal Antidiabetic Medicines (CIHR-TAAM) was instated in 2003 in an effort to find culturally relevant complementary and alternative approaches to T2D prevention and management for Canadian Aboriginal diabetics. Seventeen plant species stemming from the James Bay Cree traditional pharmacopeia were identified through ethnobotanical surveys and tested using a comprehensive platform of bioassays and animal models of obesity and diabetes to identify the plants' capacity to improve glycemic control [11, 25-28]. Cree community members also encouraged us to study the potential of the plants to protect kidney cells, since $\mathrm{DN}$ is quite prevalent in the James Bay area $[15,16]$.

In current study, we therefore sought to determine the activity of the same 17 plant extracts to afford renal protection and, hence, their potential to mitigate DN. To achieve this, we developed a bioassay based on well-known MDCK cells, a kidney cell of distal tubule origin, that we stressed with hypertonic medium to induce apoptosis [24, 29-33]. We then used flow cytometry and staining reagents for apoptosis (AnnV) and necrosis (PI). Finally, we assessed the role of several caspases in order to begin understanding mechanisms underlying the anti-apoptotic activity of certain plant species.

\section{Methods}

\section{Cell culture}

MDCK cells were generously provided by Dr. Josette Noël (Department of Pharmacology and Physiology, Université de Montréal) and grown in Eagle's Minimum Essential Medium (EMEM) supplemented with 10\% fatal bovine serum (FBS) and 0.5\% antibiotics (PS: Penicillin $100 \mathrm{U} / \mathrm{mL}$, Streptomycin $100 \mu \mathrm{g} / \mathrm{mL}$ ) and equilibrated with $5 \% \mathrm{CO} 295 \%$ air at $37{ }^{\circ} \mathrm{C}$. Upon reaching subconfluence, cells were gently detached using $0.25 \%$ trypsin.

\section{Plant extract preparation}

A total of 17 Cree medicinal plant species were the object of the current study (Table 1) and their respective maximal nontoxic concentrations (see below) used in MDCK cell line are listed in Table 2. Each species of the 17 plant samples were collected in CEI territory and prepared from air-dried and ground plant material according to previously published methods [27, 28]. Authorization for plant sample collection was obtained and managed by a comprehensive research agreement convened between the three Canadian universities involved (Université de Montréal, McGill University, University of Ottawa), the participating Cree First Nations and the Cree Board of Health and Social Services of James Bay [34]. Dr. Alain Cuerrier, a seasoned taxonomist, ascertained the botanical identity of the plant species and voucher specimens have been deposited at the herbarium of the Montreal Botanical Garden [11]. The collected plant samples were extracted with a standard $80 \%$ aqueous ethanol protocol as previously described $[27,28]$. All the plant extracts have been well characterized in terms of their phytochemical content in previous studies from our laboratory and that of others (shown in Table 1) [34-84]. All extracts were freezedried overnight using a Super Moudylo freeze-dryer (TheromFisher, Brockville, ON, Canada). They were then stored at $4{ }^{\circ} \mathrm{C}$ in amber containers in a dessicator, both of which were flushed free of oxygen. In such conditions, extracts maintained a stable phytochemical profile and biological activity for several years, as tested using HPLC analyses with different detection systems (e.g. diode array and mass spectrometer) and using several cellbased bioassays.

Stock solutions of each of the 17 plant extracts were prepared in DMSO with concentrations ranging from 5 to $200 \mathrm{mg} / \mathrm{mL}$. They were diluted in culture medium to the working concentrations shown in Table 2 (the final concentration of DMSO was $0.1 \%$ for all the treatments).

\section{Determination of maximal nontoxic plant extract concentrations}

Before screening the plants, maximal nontoxic concentrations were determined by cytotoxicity test that reflects the level of lactate dehydrogenase (LDH) release (LDH Colorimetric kit; Roche, Mannheim, Germany). Cells were seeded at the density of $1.5 \times$ $10^{5} /$ well on 6 -well plates. Medium was refreshed around $20 \mathrm{~h}$ later when $70 \%$ confluence was reached, followed by the addition of each of 17 plant extracts with a series of concentrations, respectively. The range of concentrations selected was based on our previous experience with the 17 plant extracts in other cell lines $[11,27,28]$. After 18 h' incubation, 
Table 1 Phytochemical characteristics of 17 Cree plant species

\begin{tabular}{|c|c|c|c|c|c|c|}
\hline \multicolumn{2}{|c|}{$\begin{array}{l}\text { Latin Name of } \\
\text { Plant Species }\end{array}$} & \multirow{2}{*}{$\begin{array}{l}\text { Cree Name } \\
\text { Inaast }\end{array}$} & \multirow{2}{*}{$\begin{array}{l}\text { Common Name } \\
\text { Balsam fir }\end{array}$} & \multirow{2}{*}{$\begin{array}{l}\text { Plant Part } \\
\text { Inner bark }\end{array}$} & \multirow{2}{*}{$\begin{array}{l}\text { Major Constituents } \\
\text { with Antidiabetic } \\
\text { Potential } \\
\text { Dehydroabietic acid }\end{array}$} & \multirow{2}{*}{$\begin{array}{l}\text { Other identified } \\
\text { Phytochemicals } \\
\text { Limonene, Camphene, } \\
\text { Trans-Zeatin, Dehydroju- } \\
\text { vabione, Juvabione, } \\
\text { (+)-Isojuvabiol, Abienol }\end{array}$} \\
\hline 1. & $\begin{array}{l}\text { Abies } \\
\text { balsamea } \\
\text { (L.) Mill. }\end{array}$ & & & & & \\
\hline 2. & $\begin{array}{l}\text { Alnus incana } \\
\text { subsp. rugosa } \\
\text { (Du Roi) R.T. } \\
\text { Clausen }\end{array}$ & Atuuspiih & Speckled alder & Inner bark & Oregonin & Taraxerol, Taraxerone \\
\hline 3. & $\begin{array}{l}\text { Gaultheria } \\
\text { hispidula (L.) } \\
\text { Muhl. }\end{array}$ & Piyeumanaan & Creeping snowberry & Leaves & Not determined & $\begin{array}{l}\text { P-Coumaric acid, } \\
\text { Myricetrin, Taxifolin } \\
\text { glycoside, Rutin, } \\
\text { Quercetin-3-galactoside, } \\
\text { Quercetin-3-glucoside, } \\
\text { Catechol }\end{array}$ \\
\hline 4. & $\begin{array}{l}\text { Juniperus } \\
\text { communis L. }\end{array}$ & Kaakaachuminatuk & Ground Juniper & Berries & Not determined & $\begin{array}{l}\text { Afzelechin, Sciadopitysin, } \\
\text { Longifolene, Scutellarein } \\
\text { 6-xyloside, Bilobetin, 6- } \\
\text { Hydroxyluteolin 6- } \\
\text { xyloside, Quercetin 3-O-L- } \\
\text { rhamnoside, Epiafzelechin, } \\
\text { Junionone, Junipercom- } \\
\text { noside A, Junipercomno- } \\
\text { side B, (+)-Isocupressic } \\
\text { acid, Communic acid, } \\
\text { (+)-Junenol, (+)-Sugiol, } \\
\text { Elliotinol, 1-(1,4-Dimethyl- } \\
\text { 3-cyclohexen-1-yl) etha- } \\
\text { none, Geijerone, } \\
\text { Junicedral }\end{array}$ \\
\hline 5. & $\begin{array}{l}\text { Kalmia } \\
\text { angustifolia } \mathrm{L} \text {. }\end{array}$ & Uischichipukw & Sheep laurel & Leaves & Not determined & $\begin{array}{l}\text { Asebotin, Procyanidin A2, } \\
\text { Quercetin glycoside, } \\
\text { Myricetin }\end{array}$ \\
\hline 6. & $\begin{array}{l}\text { Larix laricina } \\
\text { Du Roi } \\
\text { (K. Koch) }\end{array}$ & Waatinaakan & Tamarack & Inner bark & $\begin{array}{l}\text { Awashishinic acid, 13- } \\
\text { epitorulosol, Rhapon- } \\
\text { tigenin, Reaponticin }\end{array}$ & $\begin{array}{l}\text { Laricitrin 3-glucoside, Syr- } \\
\text { ingetin 3-glucoside }\end{array}$ \\
\hline 7. & $\begin{array}{l}\text { Lycopodium } \\
\text { clavatum L. }\end{array}$ & Pastinaakwaakin & Common clubmoss & Whole plant & Not determined & $\begin{array}{l}\text { 8-beta- } \\
\text { Hydroxylycopodine, } \\
\text { Alpha-Obscurine, O- } \\
\text { Acetylfawcettiine, Beta- } \\
\text { Dihydrolycopodine, Beta- } \\
\text { Lofoline, Lycodoline }\end{array}$ \\
\hline 8. & $\begin{array}{l}\text { Picea glauca } \\
\text { (Moench) Voss }\end{array}$ & Minhiikw & White spruce & Needles & Not determined & $\begin{array}{l}\text { Astringin, } \\
\text { Isorhapontigenin 3-O- } \\
\text { beta-D-glucopyranoside, } \\
\text { Piceatannol, } \\
\text { Isorhapontigenin }\end{array}$ \\
\hline 9. & $\begin{array}{l}\text { Picea mariana } \\
\text { (P. Mill.) BSP }\end{array}$ & linaatikw & Black spruce & Cones & Not determined & $\begin{array}{l}\text { Astringin, } \\
\text { Isorhapontigenin 3-O- } \\
\text { beta-D-glucopyranoside, } \\
\text { Piceatannol, } \\
\text { Isorhapontigenin }\end{array}$ \\
\hline 10. & $\begin{array}{l}\text { Pinus } \\
\text { banksiana } \\
\text { Lamb. }\end{array}$ & Uschisk & Jack pine & Cones & Not determined & $\begin{array}{l}\text { Pinobanksin, Cyanidin 3- } \\
\text { O-glucoside, Pinosylvin, } \\
\text { Pinosylvin methyl ether, } \\
\text { Quercetin 3,3'-diglucoside, } \\
\text { Kaempferol 3-O-beta-D- } \\
\text { (6"-coumaroyl)-glucopyra- } \\
\text { noside, Helichrysoside, } \\
\text { Peonidin 3-O-beta-D-glu- } \\
\text { copyranoside, Delphinidin } \\
\text { 3-O-beta-D- }\end{array}$ \\
\hline
\end{tabular}


Table 1 Phytochemical characteristics of 17 Cree plant species (Continued)

\begin{tabular}{|c|c|c|c|c|c|}
\hline $\begin{array}{l}\text { Latin Name of } \\
\text { Plant Species }\end{array}$ & Cree Name & Common Name & Plant Part & $\begin{array}{l}\text { Major Constituents } \\
\text { with Antidiabetic } \\
\text { Potential }\end{array}$ & $\begin{array}{l}\text { Other identified } \\
\text { Phytochemicals }\end{array}$ \\
\hline & & & & & $\begin{array}{l}\text { glucopyranoside, Petuni- } \\
\text { din 3-O-beta-D- } \\
\text { glucopyranoside, } \\
\text { Oenin, 13-Epimanoyl } \\
\text { oxide, Torulosol }\end{array}$ \\
\hline $\begin{array}{l}\text { 11. Populus } \\
\text { balsamifera } \mathrm{L} \text {. }\end{array}$ & Mash-mitush & Balsam poplar & Inner bark & Salicortin A and B & $\begin{array}{l}\text { Acetophenone, (+)-alpha- } \\
\text { Bisabolol, 2', } 4^{\prime}, 6^{\prime} \text { - } \\
\text { Trihydroxy } \\
\text { dihydrochalcone, 2',6'- } \\
\text { Dihydroxy-4'- } \\
\text { methoxydihydrochalcone, } \\
\text { 2',4',6'-Trihydroxy-4- } \\
\text { methoxydihydrochalcone }\end{array}$ \\
\hline $\begin{array}{l}\text { 12. Rhododendron } \\
\text { groenlandicum } \\
\text { (Oeder) Kron } \\
\text { and Judd }\end{array}$ & Kaachepukw & Labrador tea & Leaves & $\begin{array}{l}\text { Catechin and } \\
\text { epicatechin }\end{array}$ & $\begin{array}{l}\text { Taxifolin, Procyanidin A, } \\
\text { Dihydroquercetin, } \\
\text { (2R,3R)-3,5,7,3',4', } 5^{\prime}- \\
\text { Hexahydroxyflavanone, } \\
\text { Pyrocatechuic acid, } \\
\text { Grayanotoxin I, } \\
\text { Procyanidin B2 }\end{array}$ \\
\hline $\begin{array}{l}\text { 13. Rhododendron } \\
\text { tomentosum } \\
\text { (Stokes) } \\
\text { Harmaja } \\
\text { subsp. } \\
\text { subarcticum } \\
\text { (Harmaja) G. } \\
\text { Wallace }\end{array}$ & Wiisichipukw & Northern Labrador tea & Leaves & Not determined & $\begin{array}{l}\text { Taxifolin, Procyanidin A, } \\
\text { Dihydroquercetin, } \\
\text { (2R,3R)-3,5,7,3',4', } \text { ' }^{\prime}- \\
\text { Hexahydroxyflavanone, } \\
\text { Pyrocatechuic acid, } \\
\text { Grayanotoxin I, Taxifolin } \\
\text { glycoside }\end{array}$ \\
\hline $\begin{array}{l}\text { 14. Salix } \\
\text { planifolia } \\
\text { Pursh }\end{array}$ & Piyeuwaatikw & Tealeaf willow & Inner bark & Not determined & $\begin{array}{l}\text { Amentoflavone, Picein, } \\
\text { Myrtillin, Catechin-(2'-> } \\
\text { 2')-taxifolin, Catechin- } \\
\text { (4alpha- > 6)-epicatechin- } \\
\text { (4beta-> 8)-epicatechin, } \\
\text { Epicatechin-(4beta- > 6)- } \\
\text { epicatechin-(4beta- > 8)- } \\
\text { catechin, }\end{array}$ \\
\hline $\begin{array}{l}\text { 15. Sarracenia } \\
\text { purpurea L. }\end{array}$ & Ayikataas & Pitcher plant & Whole plant & $\begin{array}{l}\text { Isorhamnetin-3-O - } \\
\text { glucoside, } \\
\text { Kaempferol-3-O-(6"- } \\
\text { caffeoylglucoside), } \\
\text { Quercetin-3-O-galac- } \\
\text { toside, Moroniside }\end{array}$ & Histamine \\
\hline $\begin{array}{l}\text { 16. Sorbus } \\
\text { decora (Sarg.) } \\
\text { C.K. Schneid. }\end{array}$ & Maskumanaatikw & Showy mountain ash & Inner bark & 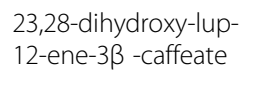 & Aucuparin \\
\hline $\begin{array}{l}\text { 17. Vaccinium } \\
\text { vitis-idaea } \mathrm{L} \text {. }\end{array}$ & Wiishichimanaanh & Mountain cranberry & Berries & $\begin{array}{l}\text { Quercetin, Quercetin- } \\
\text { 3-O -glucoside, } \\
\text { Quercetin-3-O - } \\
\text { galactoside }\end{array}$ & $\begin{array}{l}\text { Arbutin, Procyanidin A1, } \\
\text { (+)-Catechin }\end{array}$ \\
\hline
\end{tabular}

medium (contains released LDH) was collected on ice then the adherent cells (contains cellular LDH) were lysed by EMEM containing $1 \%$ Triton X-100 for $10 \mathrm{~min}$ at $37{ }^{\circ} \mathrm{C}, 5 \% \mathrm{CO}_{2}$. Subsequently, all samples were transferred to Eppendorf tubes followed by centrifugation at $250 \times \mathrm{g}, 4{ }^{\circ} \mathrm{C}, 10 \mathrm{~min}$. $\mathrm{LDH}$ in both medium and lysate buffer were quantified by a coupled enzymatic reaction in which a red formazan product was generated, the absorbance of which was measured at $490 \mathrm{~nm}$. To calculate \% cytotoxicity for each plant extracts we used the following equation:

$$
\frac{\text { Released LDH }}{\text { Total LDH (Released LDH + Cellular LDH) }} \times 100 \%
$$

Results were analyzed and used to determine the optimal nontoxic concentration for each extract. Each experiment was repeated three times. 
Table 2 List of investigated plant species and the concentrations of the extracts tested in MDCK cells

\begin{tabular}{|c|c|c|c|}
\hline Species & Abbreviations & Plant Part & Concentration $(\mu \mathrm{g} / \mathrm{mL})$ \\
\hline 1. Abies balsamea (L.) Mill. & A. balsamea & Inner bark & 25 \\
\hline 2. Alnus incana subsp. rugosa (Du Roi) R.T. Clausen & A. incana & Inner bark & 100 \\
\hline 3. Gaultheria hispidula (L.) Muhl. & G. hispidula & Leaves & 100 \\
\hline 4. Juniperus communis L. & J. communis & Berries & 25 \\
\hline 5. Kalmia angustifolia $\mathrm{L}$. & K. augustifolia & Leaves & 50 \\
\hline 6. Larix laricina Du Roi (K.Koch) & L. laricina & Inner bark & 25 \\
\hline 7. Lycopodium clavatum L. & L. clavatum & Whole plant & 100 \\
\hline 8. Picea glauca (Moench) Voss & P. glauca & Needles & 150 \\
\hline 9. Picea mariana (P. Mill.) BSP & P. mariana & Cones & 5 \\
\hline 10. Pinus banksiana Lamb. & P. banksiana & Cones & 10 \\
\hline 11. Populus balsamifera L. & P. balsamifera & Inner bark & 100 \\
\hline 12. Rhododendron groenlandicum (Oeder) Kron and Judd & R. groenlandicum & Leaves & 50 \\
\hline 13. Rhododendron tomentosum (Stokes) Harmaja subsp. subarcticum (Harmaja) G. Wallace & R. tomentosum & Leaves & 100 \\
\hline 14. Salix planifolia Pursh & S. planifolia & Inner bark & 25 \\
\hline 15. Sarracenia purpurea L. & S. purpurea & Whole plant & 100 \\
\hline 16. Sorbus decora (Sarg.) C.K. Schneid. & S. decora & Inner bark & 25 \\
\hline 17. Vaccinium vitis-idaea $\mathrm{L}$. & V. vitis-idaea & Berries & 100 \\
\hline
\end{tabular}

\section{Hypertonic stress protocol}

To screen the 17 plant extracts, cells were seeded in 6well plates at the density of $1.5 \times 10^{5} /$ well. Around $20 \mathrm{~h}$ later, $70 \%$ subconfluence was reached. Cells were then switched for $18 \mathrm{~h}$ to $700 \mathrm{mOsm} / \mathrm{L}$ hypertonic (made by addition of $200 \mathrm{mM}$ sodium chloride to EMEM culture medium) or isotonic EMEM medium without FBS [24], which contained or not each of the 17 plant extracts at their respective nontoxic maximum concentration. ZVAD-FMK, a pan caspase inhibitor, was selected as cytoprotective positive control.

\section{Flow cytometric analysis of AnnV/PI staining}

Apoptosis assays were performed using AnnV-FITC (fluorescein isothiocyanate, BD Bioscience, Mississauga, $\mathrm{ON}$ ) and PI (Thermo Fischer Scientific). $5 \mathrm{~mL}$ polystyrene tubes (BD Bioscience, Mississauga, ON)) placed in a laminar flow hood were labeled and preloaded with $500 \mu \mathrm{l}$ FBS prior to assay. After $18 \mathrm{~h}$ 'treatment, medium was transferred and collected in prepared polystyrene tubes; adherent cells were washed once with $1 \mathrm{~mL}$ PBS then harvested with $250 \mu \mathrm{l} 0.25 \%$ trypsin followed by another $1 \mathrm{~mL}$ PBS wash; all polystyrene tubes were subjected to centrifugation at $250 \mathrm{~g}, 4{ }^{\circ} \mathrm{C}, 5 \mathrm{~min}$. Subsequently, supernatant was discarded and cell pellets resuspended in $500 \mu \mathrm{L}$ of ice cold binding buffer (10 mM Hepes pH 7.4, $150 \mathrm{mM} \mathrm{NaCl}, 5 \mathrm{mM} \mathrm{KCl}$, $1 \mathrm{mM} \mathrm{MgCl} 2,1.8 \mathrm{mM} \mathrm{CaCl}_{2}$ ). Cell suspensions were then mixed with $2 \mu \mathrm{L}$ of AnnV-FITC (AnnV) and $1 \mu \mathrm{L}$ of PI. After incubation on ice for $5 \mathrm{~min}$ in the dark, healthy and damaged cells were determined and analyzed using a FACSCanto II (BD, Biosciences, Bedford, MA, USA) flow cytometer and FlowJo software. Positive staining was confirmed under fluorescence microscopy. Each experiment was repeated three times. As illustrated in the Results section below, $\mathrm{PI}^{+}$Quadrants Q1 and Q2 respectively represent necrosis and late stage apoptosis/secondary necrosis; Q4 Quadrant represents viability $\left(\mathrm{AnnV}^{-} / \mathrm{PI}^{-}\right)$; Q3 Quadrant $\left(\mathrm{AnnV}^{+} / \mathrm{PI}^{-}\right)$represents early stage apoptosis.

\section{Flow cytometry analysis of caspase 3, 8, 9}

As described in the Results section, we selected a subset of plant extracts to study potential underlying mechanisms of MDCK cell protection. Consequently, caspase $3,8,9$ assays were performed according to manufacturer's protocol by using the CaspGLOW ${ }^{\mathrm{rm}}$ Fluorescein Active Caspase Staining Kit (eBioscience, San Diego, CA, USA). Briefly, cells were detached as described above for AnnV and PI staining before CaspGLOW ${ }^{\mathrm{m}}$ Fluorescein Active Caspase staining was applied. After centrifugation at $250 \mathrm{~g}, 4{ }^{\circ} \mathrm{C}, 5 \mathrm{~min}, 300 \mu \mathrm{L}$ EMEM containing $1 \mu \mathrm{L}$ CaspGLOW ${ }^{\mathrm{TM}}$ Fluorescein Active Caspase was added to each tube, then transferred in a $37{ }^{\circ} \mathrm{C}$ incubator with $5 \% \mathrm{CO}_{2}$ for $45 \mathrm{~min}$. Subsequently, cells were subjected three times to a course of wash and spin-down (centrifugation at $500 \mathrm{~g}, 5 \mathrm{~min}$ ) at room temperature. Finally, all tubes were subjected to flow cytometry for analysis of respective caspase staining by FACSCanto II (BD, Biosciences, Bedford, MA, USA) flow cytometer and FlowJo software. This assay utilizes inhibitors specific for cleaved caspase-3, -8 and -9 , respectively. 
They are directly conjugated to FITC for the detection system. These reagents are cell permeable, non-toxic and irreversibly bind to the cleaved caspase 3,8 , and 9, respectively. Detection of the labeled cells can be determined by flow cytometry.

\section{Statistical analysis}

Results are presented as mean \pm SEM of 3 independent experiments with triplicate for each sample. Statistical comparisons between the experimental groups were analyzed by one-way ANOVA and the Bonferroni test as appropriate in software Prism 6 (GraphPad Software Inc., San Diego, CA, USA). A $P$ value below 0.05 was considered statistically significant.

\section{Results}

\section{Determination of maximal nontoxic plant extract} concentrations

MDCK cells were treated with 17 plant extracts at different concentrations, respectively. After an overnight incubation (18 h), LDH release was measured. Maximal nontoxic concentrations were determined and results are listed in Table 2. At concentrations listed, all plant extracts exhibited LDH release values that did not exceed $5-10 \%$ beyond values obtained with DMSO alone.

\section{In vitro screen of renal protective potential of 17 antidiabetic medicinal plant extracts and analysis by flow cytometry}

In order to identify the respective renal protective and anti-apoptotic potential of the 17 plant extracts in vitro, AnnV/PI double staining was performed. Examined by fluorescent-based flow cytometry and compared to isotonic EMEM (Fig. 1a), $700 \mathrm{mOsm} / \mathrm{L}$ hypertonic stress (Fig. 1b) induced substantial $\mathrm{PI}^{+}$(necrosis and late stage apoptosis/secondary necrosis, Q1 and Q2 Quadrants) as well as $\mathrm{AnnV}^{+} / \mathrm{PI}^{-}$(early stage apoptosis, Q3 Quadrant) signals in MDCK cells. We also used Z-VAD-FMK as a positive cytoprotective control. It is a commonly recognized pan caspase inhibitor, exerting its protective role by irreversibly binding to the catalytic site of caspase proteases [85]. Accordingly, Z-VAD-FMK efficiently protected MDCK cells from the deleterious effects of hypertonic stress (Fig. 1c). In the presence of such $700 \mathrm{mOsm} / \mathrm{L}$ hypertonic stress (itself alone resulting in only $53.8 \% \mathrm{AnnV}^{-} / \mathrm{PI}^{-}$staining - viable cells), all plant extracts, except S. purpurea and $K$. augustifolia, variably yet significantly improved cell viability as assessed by the change in $\mathrm{AnnV}^{-} / \mathrm{PI}^{-}$staining (Fig. 1d). Among the 17 plant extracts, G. hispidula, S. planifolia and A. balsamea were most active, respectively increasing $\mathrm{AnnV}^{-} / \mathrm{PI}^{-}$staining (viable cells) by $33.5 \%, 27.7 \%$ and $26.6 \%$, relative to hypertonic stress alone $(P<0.0001$, Fig. $1 \mathrm{~d})$. In addition, the difference in $\mathrm{AnnV}^{-} / \mathrm{PI}^{-}$staining observed in the $G$. hispidula group was statistically similar to that seen in the control (isotonic EMEM) and in the positive control Z-VAD-FMK group. On the other hand, K. augustifolia was the only plant extract to worsen cell viability under hypertonic stress; in fact, it further reduced $\mathrm{AnnV}^{-} / \mathrm{PI}^{-}$staining $(-12.9 \%$ relative to hypertonic stress, $P<0.001$, Fig. 1d).

Statistical analysis from Q3 Quadrant $\left(\mathrm{AnnV}^{+} / \mathrm{PI}^{-}\right.$, Fig. 1e) indicated that hypertonic stress caused a considerable increase of early stage apoptosis (23.5\%) compared to isotonic EMEM $(0.3 \%, P<0.0001)$. A . balsamea, G. hispidula and L. laricina were the most powerful plants protecting against early stage apoptosis, respectively reducing $\mathrm{AnnV}^{+} / \mathrm{PI}^{-}$staining by $18.4 \%, 15.9 \%$ and $15.8 \%$ relative to hypertonic stress alone $(P<0.0001$, Fig. 1e). Most importantly, A. balsamea extract yielded results that were statistically similar to that of the isotonic EMEM group (23.2\% reduction in $\mathrm{AnnV}^{+} / \mathrm{PI}^{-}$staining relative to hypertonic stress, $P<0.0001$, Fig. 1 e) and the Z-VAD-FMK group (22.8\% reduction in $\mathrm{AnnV}^{+} / \mathrm{PI}^{-}$staining relative to hypertonic stress, $P<0.0001$, Fig. 1e). Again, $K$. augustifolia exhibited its apparent renal toxic action by increasing $\mathrm{AnnV}^{+} / \mathrm{PI}^{-}$staining relative to hypertonic stress by as much as $25.0 \%(P<0.0001$, Fig. 1 e $)$.

We then sought to carry out further analysis to begin understanding potential underlying mechanisms, notably in relation to renal cell apoptosis. Based on the results presented above, we therefore selected a subset of five species. We selected G. hispidula and A. balsamea as representatives of the best plant species to improve $\mathrm{AnnV} \mathrm{V}^{-} / \mathrm{PI}^{-}$staining and reduce $\mathrm{AnnV} \mathrm{V}^{+} / \mathrm{PI}^{-}$staining. $R$. tomentosum and $R$. groenlandicum were selected as species that had moderate effects and S. purpurea as one of the least effective plant species.

\section{Mechanism investigation Cleaved caspase 3 activity}

The activity of cleaved (active) caspase 3 following various treatments was then assessed by flow cytometry analysis (Fig. 2, panels a-d). The proportion of cells exhibiting staining for active caspase 3, a hallmark of apoptosis, was significantly increased in the hypertonic stress treated group (Fig. 2b). In comparison, the isotonic EMEM group (Fig. 2a) had a proportion of caspase 3 positive cells that was $48.3 \%$ lower than hypertonic stress $(P<0.01$, Fig. $2 \mathrm{a}-\mathrm{e})$. As a positive control, pan caspase inhibitor Z-VAD-FMK largely suppressed the hypertonically induced activity of cleaved caspase 3 (71.2\% lower than hypertonic stress, $P<0.001$, Fig. 2c and e), this effect reaching levels even lower than the isotonic EMEM group (Fig. 2e). Among the representative plant species selected from our primarily screen, a statistically significant reduction in activity of cleaved 


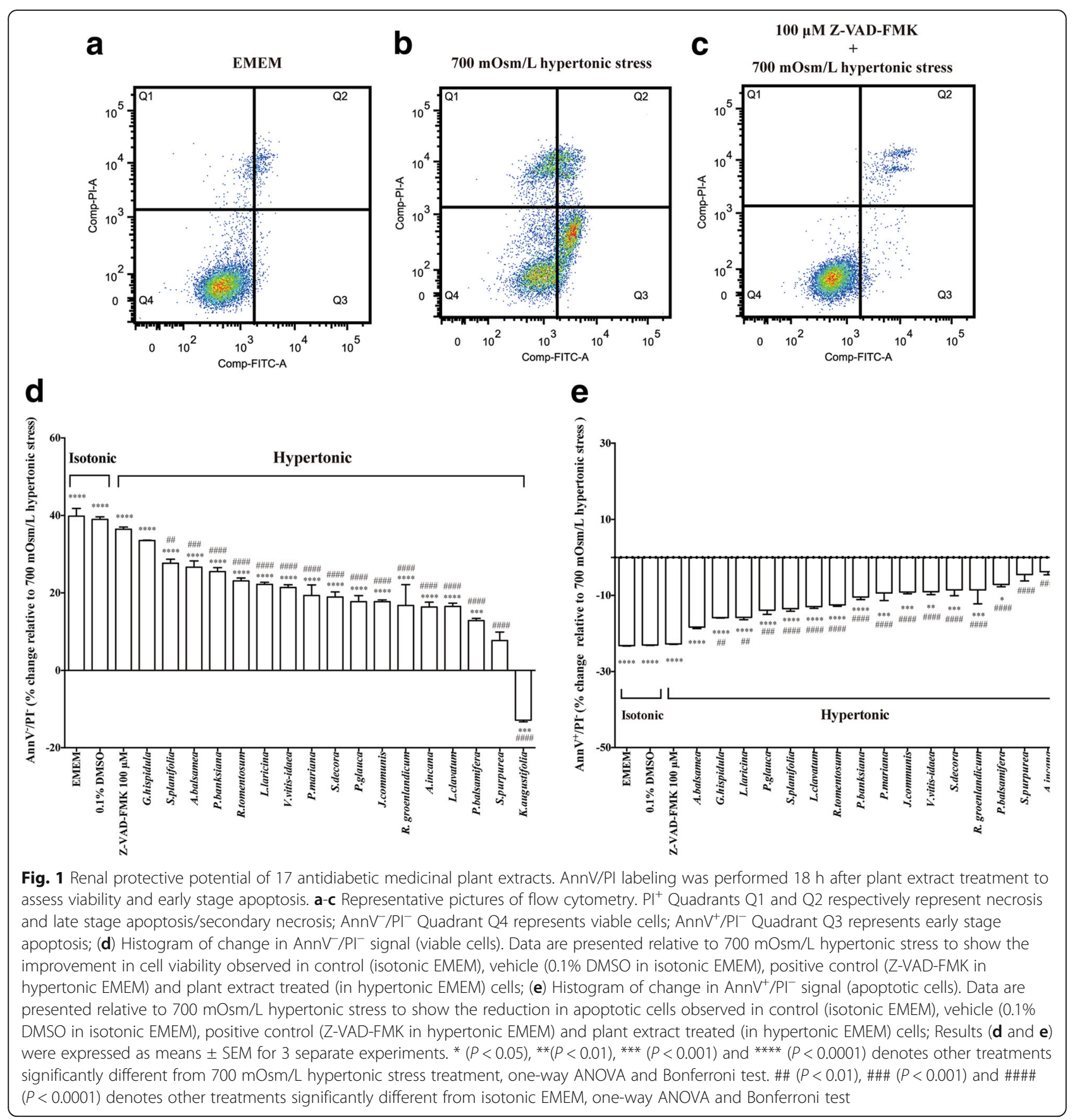

caspase 3 was observed for A. balsamea (Fig. 2d and e) and $R$. tomentosum (59.8\% and $42.3 \%$ lower than hypertonic stress, respectively, $P<0.01$, Fig. $2 \mathrm{e})$. G. hispidula and $R$. groenlandicum afforded weak protection against cleaved caspase 3 activation induced by hypertonic stress; their caspase 3 activity lying between isotonic EMEM and hypertonic stress group (N.S. versus either group, Fig. 2e). In contrast, $S$. purpurea exhibited more cleaved caspase 3 activity compared to hypertonic stress treated group $(44.5 \%$ higher than hypertonic stress, $P<0.001$, Fig. 2e). Aside from $R$. tomentosum, these results are in accordance with the rank order of cytoprotection observed in our primarily screen.

\section{Cleaved caspase 8 activity}

Secondly, the activity of cleaved caspase 8 , which indicates a death receptor signaling pathway, was also assessed (Fig. 3, panels a-d). After MDCK cells were stressed by hypertonic medium $(700 \mathrm{mOsm} / \mathrm{L})$ for $18 \mathrm{~h}$, the level of cleaved caspase 8 became significantly higher (22.5\%, Fig. 3b) compared to that of the isotonic EMEM group (8.5\%, $\mathrm{P}<0.01$, Fig. 3a). The pan-caspase inhibitor 

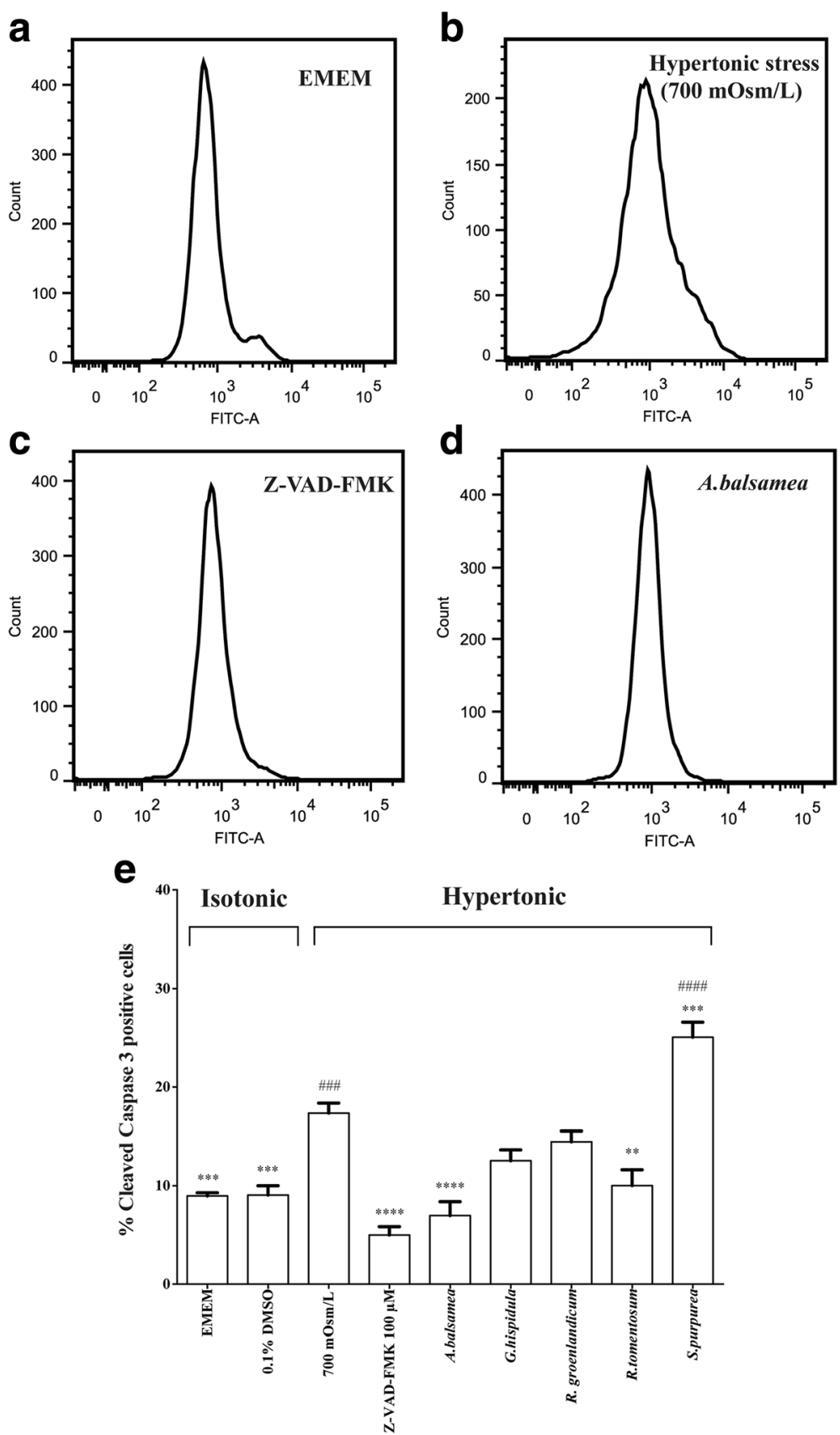

Fig. 2 Cleaved caspase 3 activity. Cleaved caspase 3 activity test was performed $18 \mathrm{~h}$ after the treatment with respective plant extracts. (a-d) Representative pictures of flow cytometry. Ordinate indicates cell count whereas abscissa represents fluorescence signal strength. From left to right, 1st peak indicates procaspase 3 and 2nd peak represents cleaved caspase 3 activity. e Histogram of percent cleaved caspase 3 positive cells. The percent cleaved caspase 3 activity was calculated as the area of 2 nd peak/total area $\times 100$. Results were expressed as means \pm SEM for 3 separate experiments. ${ }^{*}(P<0.05),{ }^{* *}(P<0.01),{ }^{* * *}(P<0.001)$ and ${ }^{* * * *}(P<0.0001)$ denotes other treatments significantly different from $700 \mathrm{mOsm} / \mathrm{L}$ hypertonic stress treatment, one-way ANOVA and Bonferroni test. \#\# $(P<0.01)$, \#\#\# $(P<0.001)$ and \#\#\#\# $(P<0.0001)$ denotes treatment groups significantly different from isotonic EMEM, one-way ANOVA and Bonferroni test

Z-VAD-FMK (Fig. 3, panels $\mathrm{c}$ and e) significantly reduced the proportion of cleaved caspase 8 positive cells to $3.7 \%$, slightly lower than isotonic EMEM values (Fig. 3, panels a and e). Except for Z-VAD-FMK, the rest of the selected plant species seemed ineffective at decreasing the proportion of cleaved caspase 8 in a statistically significant manner. In fact, S. purpurea and $R$. groenlandicum enhanced the proportion of cleaved caspase 8 positive cells $(30.5 \%$ and $31.1 \%$, respectively, $P<0.0001$ Fig. 3e). 

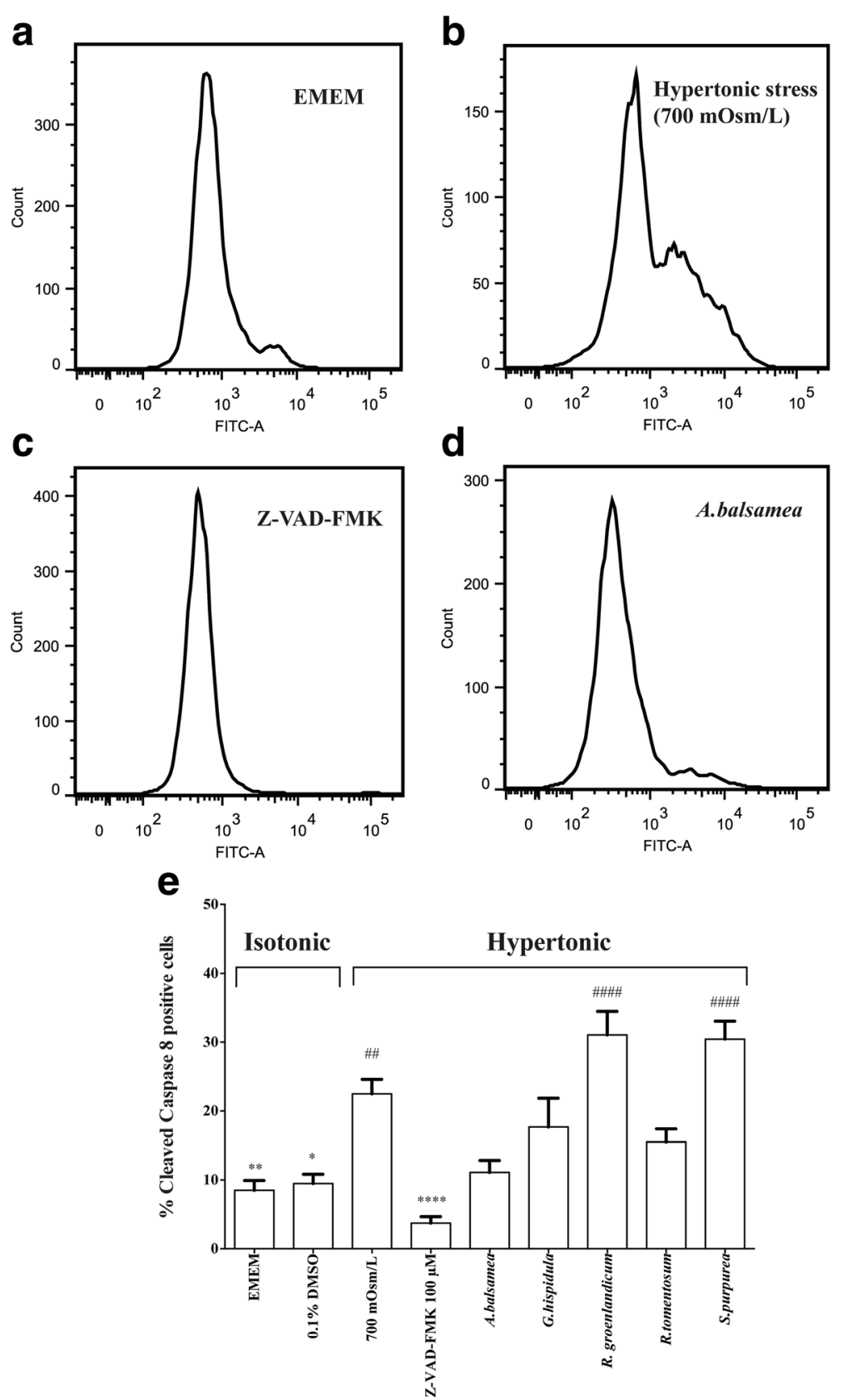

Fig. 3 Cleaved caspase 8 activity. Cleaved caspase 8 activity test was performed $18 \mathrm{~h}$ after the treatment with respective plant extracts. a-d Representative pictures of flow cytometry. Ordinate indicates cell count whereas abscissa represents fluorescence signal strength. From left to right, 1st peak indicates procaspase 8 and 2nd peak represents cleaved caspase 8 activity. e Histogram of percent cleaved caspase 8 positive cells. The percent cleaved caspase 8 activity was calculated as the area of 2 nd peak/total area $\times 100$. Results were expressed as means \pm SEM for 3 separate experiments. ${ }^{*}(P<0.05),{ }^{* *}(P<0.01),{ }^{* * *}(P<0.001)$ and ${ }^{* * *}(P<0.0001)$ denotes other treatments significantly different from $700 \mathrm{mOsm} / \mathrm{L}$ hypertonic stress treatment, one-way ANOVA and Bonferroni test. \#\# $(P<0.01)$, \#\#\# $(P<0.001)$ and \#\#\#\# $(P<0.0001)$ denotes treatment groups significantly different from isotonic EMEM, one-way ANOVA and Bonferroni test

\section{Cleaved caspase 9 activity}

We finally analyzed the activity of cleaved caspase 9, indicative of the mitochondrial apoptotic pathway, using fluorescent staining and flow cytometry (Fig. 4, panels a-d). Compared to the value of $7.2 \%$ obtained in the isotonic EMEM group (Fig. 4, panels a and e), hypertonic stress enhanced the proportion of cleaved caspase 9 positive cells to $23.4 \%$ ( $P<0.0001$, Fig. 4 , panels $\mathrm{b}$ and e). As expected the positive cytoprotective control Z-VAD-FMK reduced the effect of hypertonic stress on caspase 9 positive cells $(6.9 \%, P<0.0001$ compared to hypertonic stress group, Fig. 4, panels $\mathrm{c}$ and e). In comparison, the 

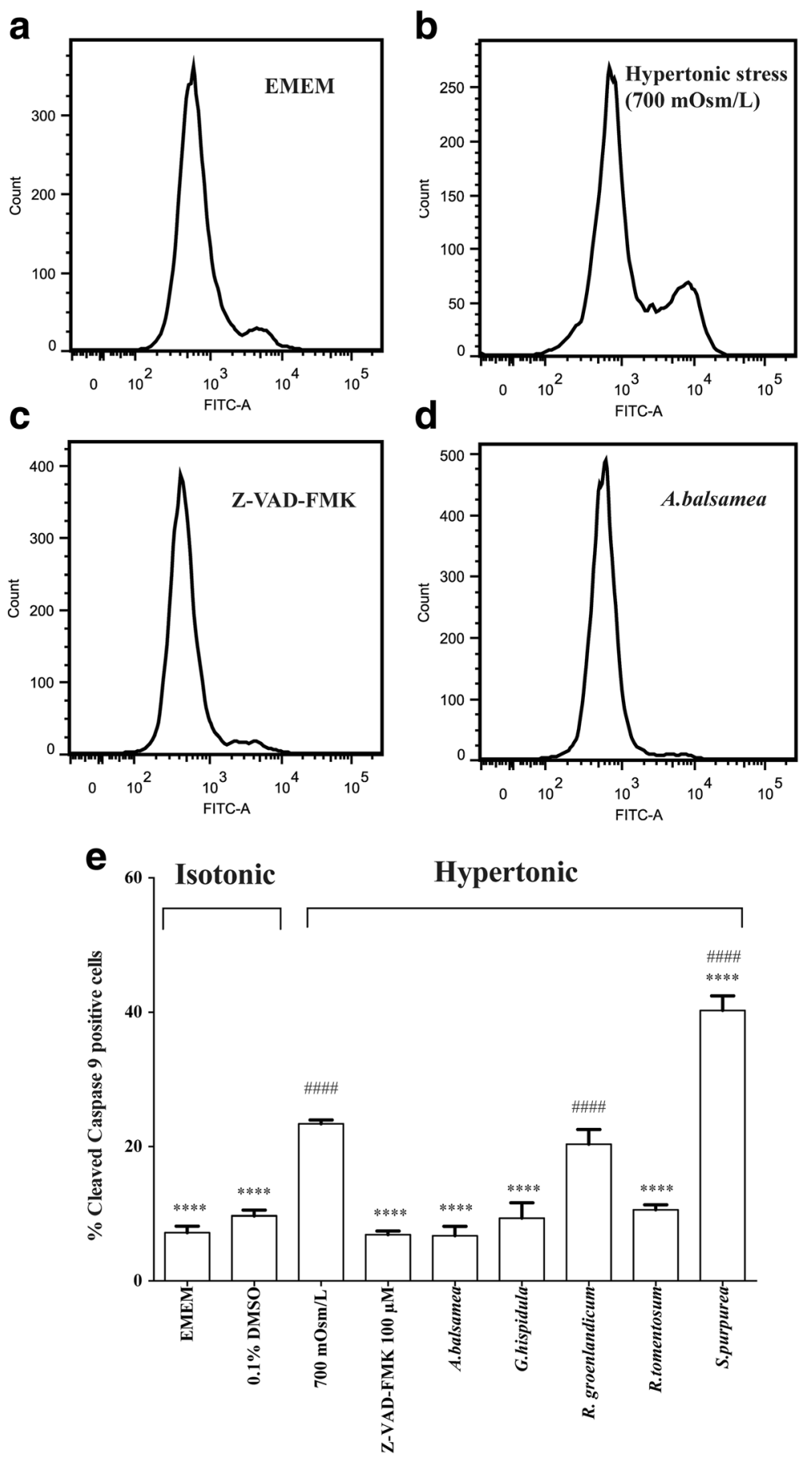

Fig. 4 Cleaved caspase 9 activity. Cleaved caspase 9 activity test was performed $18 \mathrm{~h}$ after the treatment with respective plant extracts. a-d Representative pictures of flow cytometry. Ordinate indicates cell count whereas abscissa represents fluorescence signal strength. From left to right, 1st peak indicates procaspase 9 and 2nd peak represents cleaved caspase 9 activity. e Histogram of percent cleaved caspase 9 positive cells. The percent cleaved caspase 9 activity was calculated as the area of 2 nd peak/total area $\times 100$. Results were expressed as means \pm SEM for 3 separate experiments. ${ }^{*}(P<0.05),{ }^{* *}(P<0.01),{ }^{* * *}(P<0.001)$ and ${ }^{* * *}(P<0.0001)$ denotes other treatments significantly different from $700 \mathrm{mOsm} / \mathrm{L}$ hypertonic stress treatment, one-way ANOVA and Bonferroni test. \#\# $(P<0.01)$, \#\#\# $(P<0.001)$ and \#\#\# $(P<0.0001)$ denotes treatment groups significantly different from isotonic EMEM, one-way ANOVA and Bonferroni test 
effective Cree plant treatments were A. balsamea, G. hispidula and $R$. tomentosum, with corresponding percentage of cleaved caspase 9 at $6.8 \%, 9.4 \%$ and $10.6 \%$, respectively $(P<0.0001$ compared to hypertonic stress, Fig. 4, panels d and e). R. groenlandicum and S. purpurea were again not only ineffective at suppressing the production of cleaved caspase 9 but $S$. purpurea also significantly increased its expression $(P<0.0001$, Fig. 4e).

\section{Discussion}

The aim of the current study was to begin evaluating the nephroprotective capacity of 17 Cree medicinal plants that were identified as having significant antidiabetic potential in several bioassays related to glucose and lipid homeostasis as well as in animal models of obesity and diabetes [26, 86]. As mentioned, our CEI partners highlighted the fact that their population was suffering disproportionately from $\mathrm{DN}[34,87]$ and wanted us to look into renal protection stemming from their traditional medicinal plants.

We therefore selected the MDCK cell line, which is a very well characterized renal tubular cell model that can serve to assess cytoprotection against various insults [24, 29-33]. We also selected hypertonic stress to cause cell death, notably involving apoptosis [24]. In preliminary experiments, we challenged MDCK cells with different medium osmolarities (including 300, 400, 500, 600, 700 and $800 \mathrm{mOsm} / \mathrm{L}$ hypertonic medium, data not illustrated) and found that $700 \mathrm{mOsm} / \mathrm{L}$ was the ideal concentration to induce substantial apoptosis, which could be used to test the anti-apoptotic potential of the 17 plant species. This also corresponded with the concentration used successfully by other researchers in the same cell line [24]. This is pertinent in the context of the present studies, since renal tubular apoptosis is recognized as a major contributor for the development of DN [21-23]. Our results with AnnV/PI double staining and flow cytometry clearly demonstrate that a $700 \mathrm{mOsm} / \mathrm{L}$ hypertonic stress resulted in significant increases in cell death ( $\mathrm{PI}^{+}$quadrants Q1 and Q2; respectively representing necrosis and late apoptosis). Hypertonic stress also significantly enhanced the proportion of cells with $\mathrm{AnnV}^{+} / \mathrm{PI}^{-}$ staining, indicative of early apoptotic cell damage.

Also, importantly, we chose the pan caspase inhibitor Z-VAD-FMK as a positive cytoprotective control introduced in the hypertonic medium. It was very efficient in returning the pattern of AnnV/PI staining to that seen in isotonic EMEM (no hypertonic stress). Thus, our MDCK cells provide an adequate model in which to screen for potential nephroprotective and anti-apoptotic activities of Cree antidiabetic medicinal plants.
When MDCK cells were treated with the various antidiabetic Cree plants, we obtained a wide range of effects; a number of plant extracts almost completely prevented the deleterious effects of hypertonic stress, several were moderately cytoprotective, a few were weakly so and one plant actually enhanced nephrotoxicity, namely $K$. angustifolia. Notably, G. hispidula and A. balsamea plant extracts were amongst the best performers in maintaining high viability and suppressing apoptosis, being as powerful as Z-VAD-FMK. As mentioned, Z-VAD-FMK is a pan-caspase inhibitor that acts against apoptosis by irreversibly binding to the catalytic site of caspase proteases. As also discussed, apoptosis is involved in cell damage caused by hypertonic stress and is implicated in DN [21-24]. We therefore sought to determine the potential role that caspases could play in the variable cytoprotective activity that we observed for the Cree plants.

Caspases (cysteine-aspartic proteases or cysteinedependent aspartate-directed proteases) belong to a family called cysteine proteases. They play an essential role in cell apoptosis or programmed cell death and have thus been termed "executioner" proteins [88, 89]. Caspases are regulated at a post-translational level, which allows them to be activated rapidly. Caspases are synthesized as inactive preforms and are cleaved next to aspartate residues upon activation [90]. There are socalled initiator and effector caspases. Initiator caspases possessed specific domains not encountered in effector caspases, such as caspase activation and recruitment domains (CARDs) (e.g., caspase-2 and caspase-9) or a death effector domain (DED) (caspase-8 and caspase-10). These ensure that the caspases can interact with other molecules that regulate their activation. These regulating molecules receive signals from extracellular and intracellular stimuli and interact with initiator caspases, causing their clustering. Such clustering allows initiator caspases to auto-activate and to proceed to activate effector caspases, eventually leading to the amplification of caspase activity through a protease cascade [90], considered as a positive feedback [91]. As mentioned, the activation of caspases can be initiated from extracellular stimuli involving death receptors on the plasma membrane (receptor pathway) or through intracellular stimuli centered in mitochondria (mitochondrial pathway) [92].

Death receptor stimulation activates procaspase-8, whereas the mitochondrial pathway involves the release of cytochrome $\mathrm{c}$ and other factors that activate procaspase-9 $[24,92]$. Both signaling pathways will eventually lead to downstream activation of caspase-3, which is a major effector in the caspase cascade. Since caspase-3 serves as a convergence point for different signaling pathways, it is therefore well suited as a read-out in an apoptosis assay. In the current studies, we used fluorescent 
substrates of these three major caspases to probe their activation by flow cytometry. Our results clearly show an increased activity of cleaved caspase 3, 8 and 9 activities in MDCK cells subjected to a $700 \mathrm{mOsm} /$ $\mathrm{L}$ hypertonic stress for $18 \mathrm{~h}$. Moreover, the proportion of caspase 8 and 9 "positive" cells was $22.5 \%$ and $23.4 \%$, respectively, which indicates that the death receptor and mitochondrial pathways were similarly activated in cells challenged by hypertonic medium.

When we studied the five plant species that were selected to represent strong, medium and low cytoprotective potential in AnnV/PI assays, their rank order of inhibition of hypertonic stress-induced cell damage was mostly maintained for cleaved caspases 3, 8 and 9, except for $G$. hispidula that was ineffective at reducing the activity of caspases 3 and 8 , and $R$. tomentosum that was unexpectedly effective in reducing the activity of caspases 3 and 9.

Rather limited knowledge is available regarding G. hispidula. In previous studies from our group, the plant extract exerted some cytoprotective potential in preneuronal cells subjected to hyperglycemic stress [27] and moderately stimulated AMPK in cultured hepatocytes [11]. The current studies uncovered a strong cytoprotective potential for renal tubular cells as observed through improved viability $\left(\mathrm{annV}^{-} / \mathrm{PI}^{-}\right.$staining) and reduced early stage apoptosis ( $\mathrm{annV}^{+} / \mathrm{PI}^{-}$staining). However, as mentioned G. hispidula did not succeed in significantly modulating the activities of caspases 3 and 8 in hypertonically stressed MDCK cells. This suggests that the nephroprotective activity of the plant extract may occur principally through the mitochondrial pathway (significant reduction of cleaved caspase 9) or through pathways other than the classic apoptotic signaling pathways (death receptor or mitochondrial) [93].

Meanwhile, the non-cytoprotective plant $S$. purpurea actually enhanced the activity of all cleaved caspases in hypertonically stressed MDCK cells. Hence, despite the fact that $S$. purpurea previously exhibited a positive impact on muscle cell glucose uptake [34] and, notably, cytoprotection of pre-neuronal cells (potential benefit in diabetic neuropathy [37]), the plant appears to be potentially more harmful to renal cells. Indeed, Elders have cautioned us that the pitcher plant needed to be used carefully for it is considered very powerful.

Another of the weaker nephroprotective plants in our Ann V/PI assay, namely $R$. groenlandicum, appeared to increase the activation of caspase 8 compared to hypertonic stress whereas it had no apparent effect on cleaved caspase 3 and caspase 9 activities. This result is surprising since Labrador tea ( $R$. groenlandicum) was previously observed by our group to exhibit several beneficial antidiabetic activities when tested in both in vitro bioassays [36, 94] and in vivo animal models of obesity and mild diabetes $[95,96]$. Such antidiabetic activities would be expected to improve renal function (for instance, through reduction of glycemia and improvement of insulin resistance). In fact, we observed improved micro-albuminuria, reduced fibrosis and diminished expression of $\mathrm{Bcl} 2$-modulating factor $(\mathrm{Bmf})$ in renal tissues of diet-induced obese mice treated with $R$. groenlandicum in vivo [95]. Interestingly, in the current studies, $R$. tomentosum, a close relative of $R$. groenlandicum also known as Northern Labrador tea, exhibited significant anti-apoptotic potential that was expressed more potently through the suppression of the mitochondrial apoptotic pathway than that of the death receptor pathway. Further studies will thus be necessary to ascertain the complete impacts of Labrador or Northern Labrador tea consumption on the kidney.

In contrast, $A$. balsamea clearly stands out as one of the most powerful renal protective Cree plants that exhibited important anti-apoptotic activities, especially at the level of caspases 3 and 9. Our previous work with A. balsamea extracts demonstrated that they can significantly enhance basal and insulin stimulated glucose uptake in cultured skeletal muscle cells and adipocytes [28]. The plant was also the most powerful of Cree species to mitigate liver cell glucose production mechanisms in vitro through both insulin-dependent and insulin-independent mechanisms [86]. In skeletal muscle cells, A. balsamea exerted its action through a mechanism similar to that of metformin, involving the activation of AMPK secondary to metabolic stress induced by the disruption of mitochondrial energy transduction (energy depletion), albeit with only mild effects on cell $\mathrm{pH}$ or ATP levels [97]. It is interesting to speculate that $A$. balsamea's effects on mitochondria can also result in triggering anti-apoptotic events but further studies will be necessary to address this point.

Lastly, it is acknowledged that our study provides a good assessment of the efficacy (maximal effect) of the various plant extracts, used at maximal non-toxic concentrations, but does not provide values of EC50 (improvement of cell viability) or IC50 (reduction of apoptosis and caspase activities) that can offer an indication of the relative potencies of the various plant extracts tested. This approach was selected to be consistent with our numerous previous screening studies with the same 17 plant species, carried out in various bioassays related to diabetes and/or its complications [11, 27, 28, 34, 97]. In addition, EC50 and IC50 values are usually applied to drugs and pure compounds acting on a defined target, generally a receptor, and are thus of limited interpretation when applied to complex mixtures such as crude plant extracts used herein. 


\section{Conclusion}

In summary, this study demonstrates that $A$. balsamea and G. hispidula exhibit the greatest potential of all Cree antidiabetic plants tested to protect kidney cells against damage induced by tubular apoptosis. A. balsamea appears to do so by suppressing apoptosis, most likely through actions on the mitochondrial caspase signaling pathway, whereas G. hispidula may exert its renal protective potential through mitochondrial and other pathways. In addition, the data generated in the current study suggest that this bioassay involving MDCK cells and flow cytometry may represent a useful and novel tool to screen for nephroprotective agents.

Finally, these findings may have clinical significance for the mitigation of DN that is affecting CEI communities. Indeed, Cree medicinal plant species may contain phytochemical components that can provide novel pharmacological avenues to improve DN treatment and management. More importantly, Cree traditional plant preparations hold promise as complementary therapies that are culturally adapted and respectful. As such, future clinical studies should be encouraged.

\section{Abbreviations}

AnnV: Annexin V; Bmf: Bcl2-modulating factor; CARDs: Caspase activation and recruitment domains; CEl: Cree populations of Eeyou Istchee; CIHRTAAM: The Canadian Institutes Health Research Team in Aboriginal Antidiabetic Medicines; DED: Death effector domain; DM: Diabetes mellitus; DN: Diabetes nephropathy; EMEM: Eagle's Minimum Essential Medium; ESRD: End-stage renal disease; FBS: Fatal bovine serum; FITC: Fluorescein isothiocyanate; GFR: Glomerular filtration rate; LDH: Lactate dehydrogenase; MDCK: Madin-Darnby Canine Kidney; PI: Propidium iodide; T2D: Type 2 diabetes

\section{Acknowledgements \\ We thank Shirley Campbell for precious help with experimental troubleshooting. We are also indebted to Prof. John Thor Arnason for constant support and advice in this project. Very special thanks are due to Cree Elders of Eeyou Istchii who kindly agreed to be interviewed. They made this paper possible by allowing us to use, for the purposes of this research, their knowledge related to medicinal plants transmitted to them by their predecessors. Their trust has also enabled a useful exchange between Indigenous knowledge and Western science.}

\section{Funding}

Team Grants from the Canadian Institutes of Health Research (CIHR Team in Aboriginal Antidiabetic Medicines; CTP-79855 and OP2-144645) to Pierre S. Haddad and collaborators funded these studies.

\section{Availability of data and materials}

The data and materials of this article are included within the article.

\section{Authors' contributions}

SL conceived and designed the study; he carried out the most of the experiments. SP gave comments, provided the technical support in flow cytometer and helped with data analysis. HME contributed to the study design, offered the critical revision of the manuscript and provided technical help. JFG provided valuable support with data analysis and troubleshooting. AS provided the plant extracts and carried out a thorough literature review to provide readers with a more comprehensive understanding of the phytochemical characteristics of 17 the Cree plant species. PSH oversaw the entire project and provided comments and editorial review of the manuscript. All authors read and approved the final manuscript.
Ethics approval and consent to participate

Not applicable.

\section{Consent for publication}

Not applicable.

\section{Competing interests}

The authors declare that they have no competing interests.

\section{Publisher's Note}

Springer Nature remains neutral with regard to jurisdictional claims in published maps and institutional affiliations.

\section{Author details}

${ }^{1}$ Department of Pharmacology and Physiology, Université de Montréal, P.O. Box 6128, Downtown Postal Station, Montreal, (Quebec) H3C 3J7, Canada. ${ }^{2}$ Natural Health Products and Metabolic Diseases Laboratory, CIHR Team in Aboriginal Antidiabetic Medicines and Montreal Diabetes Research Center, CRCHUM, Montreal, Canada. ${ }^{3}$ Department of Pharmacognosy, Faculty of Pharmacy, Beni-Suef University, Beni-Suef 62514, Egypt. ${ }^{4}$ Center for Advanced Research in Environmental Genomics, University of Ottawa, Ottawa K1N 6N5, Canada.

Received: 4 May 2017 Accepted: 18 January 2018

Published online: 30 January 2018

\section{References}

1. Polonsky KS. The past 200 years in diabetes. N Engl J Med. 2012;367:1332-40.

2. Ozougwu JC, Obimba KC, Belonwu CD, Unakalamba CB. The pathogenesis and pathophysiology of type 1 and type 2 diabetes mellitus. J Physiol Pathophysiol. 2013:4:46-57.

3. Tan KT, Cheah JS. Pathogenesis of type 1 and type 2 diabetes mellitus. Ann Acad Med Singap. 1990;19:506-11.

4. Hall JE, Guyton AC. Guyton and hall textbook of medical physiology. 12th ed. Philadelphia: Elsevier; 2011.

5. Wild S, Roglic G, Green A, Sicree R, King H. Global prevalence of diabetes: estimates for the year 2000 and projections for 2030. Diabetes Care. 2004;27:1047-53.

6. Amos AF, McCarty DJ, Zimmet P. The rising global burden of diabetes and its complications: estimates and projections to the year 2010. Diabet Med. 1997;14(Suppl 5):S1-85.

7. $\quad$ King H, Aubert RE, Herman WH. Global burden of diabetes, 1995-2025: prevalence, numerical estimates, and projections. Diabetes Care. 1998;21: 1414-31.

8. King $H$, Rewers M. Global estimates for prevalence of diabetes mellitus and impaired glucose tolerance in adults. WHO ad hoc diabetes reporting group. Diabetes Care. 1993;16:157-77.

9. Ekoe JM, Thouez JP, Petitclerc C, Foggin PM, Ghadirian P. Epidemiology of obesity in relationship to some chronic medical conditions among Inuit and Cree Indian populations in new Quebec, Canada. Diabetes Res Clin Pract. 1990;10(Suppl 1):S17-27.

10. Hegele RA, Cao H, Harris SB, Hanley AJ, Zinman B. The hepatic nuclear factor-1alpha G319S variant is associated with early-onset type 2 diabetes in Canadian Oji-Cree. J Clin Endocrinol Metab. 1999;84:1077-82.

11. Nachar A, Vallerand D, Musallam L, Lavoie L, Badawi A, Arnason J, et al. The action of antidiabetic plants of the canadian james bay cree traditional pharmacopeia on key enzymes of hepatic glucose homeostasis. Evid Based Complement Alternat Med. 2013:2013:189819.

12. Neel JV. Diabetes mellitus: a "thrifty" genotype rendered detrimental by "progress"? Am J Hum Genet. 1962;14:353-62.

13. Young TK, Reading J, Elias B, O'Neil JD. Type 2 diabetes mellitus in Canada's first nations: status of an epidemic in progress. CMAJ. 2000;163:561-6.

14. Kuzmina $E$, Lejeune $P$, Dannenbaum D, Torrie JE. Cree diabetes information system (CDIS) 2009 annual report. 3rd ed. Cree Board of Health and Social Services of James Bay: Montréal; 2010.

15. Obesity GD. The eating habits of the aboriginal population. Health Rep. 2008;19:21-35.

16. Hanley AJ, Harris SB, Mamakeesick M, Goodwin K, Fiddler E, Hegele RA, et al. Complications of type 2 diabetes among aboriginal Canadians: prevalence and associated risk factors. Diabetes Care. 2005;28:2054-7. 
17. Ritz E, Orth SR. Nephropathy in patients with type 2 diabetes mellitus. N Engl J Med. 1999;341:1127-33.

18. Fineberg D, Jandeleit-Dahm KA, Cooper ME. Diabetic nephropathy: diagnosis and treatment. Nat Rev Endocrinol. 2013;9:713-23.

19. Adler Al, Stratton IM, Neil HA, Yudkin JS, Matthews DR, Cull CA, et al. Association of systolic blood pressure with macrovascular and microvascular complications of type 2 diabetes (UKPDS 36): prospective observational study. BMJ. 2000;321:412-9.

20. Stratton IM, Adler Al, Neil HA, Matthews DR, Manley SE, Cull CA, et al. Association of glycaemia with macrovascular and microvascular complications of type 2 diabetes (UKPDS 35): prospective observational study. BMJ. 2000;321:405-12.

21. Diabetes HSL. renal tubular cell apoptosis. World J Diabetes. 2013;4:27-30

22. Kumar D, Robertson S, Burns KD. Evidence of apoptosis in human diabetic kidney. Mol Cell Biochem. 2004;259:67-70

23. Sanchez-Nino MD, Sanz AB, Lorz C, Gnirke A, Rastaldi MP, Nair V, et al. BASP1 promotes apoptosis in diabetic nephropathy. J Am Soc Nephrol. 2010;21:610-21.

24. Horio M, Ito A, Matsuoka Y, Moriyama T, Orita Y, Takenaka M, et al. Apoptosis induced by hypertonicity in Madin Darley canine kidney cells: protective effect of betaine. Nephrol Dial Transplant. 2001;16:483-90

25. Fraser MH, Cuerrier A, Haddad PS, Arnason JT, Owen PL, Johns T. Medicinal plants of Cree communities (Quebec, Canada): antioxidant activity of plants used to treat type 2 diabetes symptoms. Can J Physiol Pharmacol 2007;85:1200-1214.

26. Haddad PS, Musallam L, Martineau LC, Harris C, Lavoie L, Arnason JT, et al. Comprehensive evidence-based assessment and prioritization of potential antidiabetic medicinal plants: a case study from canadian eastern james bay cree traditional medicine. Evid Based Complement Alternat Med. 2012;2012:893426.

27. Harbilas D, Martineau LC, Harris CS, Adeyiwola-Spoor DC, Saleem A, Lambert $J$, et al. Evaluation of the antidiabetic potential of selected medicinal plant extracts from the Canadian boreal forest used to treat symptoms of diabetes: part II. Can J Physiol Pharmacol. 2009;87:479-92.

28. Spoor DC, Martineau LC, Leduc C, Benhaddou-Andaloussi A, Meddah B, Harris $C$, et al. Selected plant species from the Cree pharmacopoeia of northern Quebec possess anti-diabetic potential. Can J Physiol Pharmacol. 2006;84:847-58

29. Erkan E, Devarajan P, Schwartz GJ. Apoptotic response to albumin overload: proximal vs. distal/collecting tubule cells. Am J Nephrol. 2005;25:121-31.

30. Hizoh I, Haller C. Radiocontrast-induced renal tubular cell apoptosis: hypertonic versus oxidative stress. Investig Radiol. 2002;37:428-34.

31. Terada Y, Inoshita S, Hanada S, Shimamura H, Kuwahara M, Ogawa W, et al. Hyperosmolality activates Akt and regulates apoptosis in renal tubular cells. Kidney Int. 2001;60:553-67.

32. Yoshida T, Yoshino J, Hayashi M, Saruta T. Identification of a renal proximal tubular cell-specific enhancer in the mouse 25-hydroxyvitamin d lalphahydroxylase gene. J Am Soc Nephrol. 2002;13:1455-63.

33. Zhang B, Suzuki JS, Nishimura N, Tohyama C. Difference in cadmium cytotoxicity in two kidney cell lines (LLC-PK(1) and MDCK) with special reference to metallothionein. Toxicol in Vitro. 1995;9:765-72.

34. Shang N, Saleem A, Musallam L, Walshe-Roussel B, Badawi A, Cuerrier A, et al. Novel approach to identify potential bioactive plant metabolites: pharmacological and metabolomics analyses of ethanol and hot water extracts of several Canadian medicinal plants of the Cree of Eeyou Istchee. PLoS One. 2015;10:e0135721.

35. Yong Y, Saleem A, Guerrero-Analco JA, Haddad PS, Cuerrier A, Arnason JT, et al. Larix Laricina bark, a traditional medicine used by the Cree of Eeyou Istchee: antioxidant constituents and in vitro permeability across Caco-2 cell monolayers. J Ethnopharmacol. 2016;194:651-7.

36. Eid HM, Ouchfoun M, Saleem A, Guerrero-Analco JA, Walshe-Roussel B, Musallam $L$, et al. A combination of (+)-catechin and (-)-epicatechin underlies the in vitro adipogenic action of Labrador tea (Rhododendron Groenlandicum), an antidiabetic medicinal plant of the eastern James Bay Cree pharmacopeia. J Ethnopharmacol. 2016;178:251-7

37. Harris CS, Asim M, Saleem A, Haddad PS, Arnason JT, Bennett SA. Characterizing the cytoprotective activity of Sarracenia Purpurea L., a medicinal plant that inhibits glucotoxicity in $\mathrm{PC} 12$ cells. BMC Complement Altern Med. 2012;12:245.
38. Shang N, Guerrero-Analco JA, Musallam L, Saleem A, Muhammad A, Walshe-Roussel $B$, et al. Adipogenic constituents from the bark of Larix Laricina du Roi (K. Koch; Pinaceae), an important medicinal plant used traditionally by the Cree of Eeyou Istchee (Quebec, Canada) for the treatment of type 2 diabetes symptoms. J Ethnopharmacol. 2012;141:1051-7.

39. Nachar A, Saleem A, Arnason JT, Haddad PS. Regulation of liver cell glucose homeostasis by dehydroabietic acid, abietic acid and squalene isolated from balsam fir (Abies Balsamea (L.) mill.) a plant of the eastern James Bay Cree traditional pharmacopeia. Phytochemistry. 2015;117:373-9.

40. Guerrero-Analco JA, Muhammad A, Saleem A, Martineau LC, Musallam L, Eid HM, et al. Bioactive phytochemicals from Canadian boreal Forest species used traditionally by eastern James Bay Cree aboriginals to treat diabetes mellitus. In: Jetter R, editor. Phytochemicals - biosynthesis, function and application: volume 44. New York: Springer International Publishing: 2014. p. 57-84.

41. Uyeo S, Okada J, Matsunago S. Selenium Dehydrogenation Of Abieslactone. Yakugaku Zasshi. 1964;84:453-7.

42. Steglich W, Klaar M, Zechlin L, Hecht HJ. Abietospiran, the triterpene from the bark of the white fir (Abies Alba). Angew Chem Int Ed. 1979;18 doi:10.1002/anie.197906981.

43. Baxter H, Harborne JB, Moss GP. Phytochemical Dictionary: A Handbook of Bioactive Compounds from Plants. 2nd ed. London et Philadelphia: Taylor \& Francis: CRC press; 1999

44. Manville JF, Kriz CD. Juvabione and its analogues.: IV. Isolation, identification, and occurrence of juvabione, juvabiol, and epijuvabiol from the whole wood of Abies Lasiocarpa. Can J Chem. 1977;55:2547-53.

45. Gray PS, Mills JS. 1109. The isolation of abienol from Canada balsam, the oleoresin of Abies Balsamea(L.) mill. J Chem Soc. 1964; doi:10.1039/JR9640005822.

46. Ryabinin AA. Journal of general chemistry of the Union of Soviet Socialist Republics. 1st ed. New York: Consultants Bureau Enterprises; 1962.

47. Saleem A, Harris CS, Asim M, Cuerrier A, Martineau L, Haddad PS, et al. A RPHPLC-DAD-APCI/MSD method for the characterisation of medicinal Ericaceae used by the Eeyou Istchee Cree first nations. Phytochem Anal. 2010;21:328-39.

48. Teresa JdP JG. Urones, Basabe P. Llanos A Anales de Quim. 1977;73:463.

49. Phytochemical L-ZE. Studies on flavonoids and other compounds of juniper fruits. Pol J Chem. 1980;54:213-9.

50. Baker W, Finch ACM, Ollis WD, Robinson KW. 280. The structures of the naturally occurring biflavonyls. J Chem Soc. 1963; doi:10.1039/JR9630001477.

51. Nakanishi T, lida N, Inatomi Y, Murata H, Inada A, Murata J, et al. Neolignan and flavonoid glycosides in Juniperus Communis Var. Depressa. Phytochemistry. 2004;65:207-13.

52. Weinges K, Göritz K, Nader F. Zur Kenntnis der Proanthocyanidine, XI1 Konfigurationsbestimmung von $\mathrm{C} 30 \mathrm{H} 26 \mathrm{O} 12$-Procyanidinen und Strukturaufklärung eines neuen Procyanidins. European J Org Chem. 1968: 715:164-71.

53. Thomas AF, Ozainne M. "Junionone" [1-(2,2-dimethylcyclobutyl)but-1-en-3one], the first vegetable monocyclic cyclobutane monoterpenoid. J Chem Soc Chem Commun. 1973; doi:10.1039/C39730000746.

54. Kagawa K, Tokura K, Uchida K, Kakushi H, Shike T, Kikuchi J, et al. Platelet aggregation inhibitors in a Bhutanese medicinal plant, Shug Chher. Chem Pharm Bull (Tokyo). 1993;41:1604-7.

55. Arya VP, Erdtman H, Kubota T. Chemistry of the natural order cupressales-41: the structure and stereochemistry of communic acid Tetrahedron. 1961;16:255-63.

56. Hinge VK, Wagh AD, Paknikar SK, Bhattacharyya SC. Terpenoids—LXXI Tetrahedron. 1965:21:3197-203.

57. Schneider I, Gibbons S, Bucar F. Inhibitory activity of Juniperus Communis on 12(S)-HETE production in human platelets. Planta Med. 2004;70:471-4.

58. Arya VP, Enzell C, Erdtman H, Kubota T. Communic acid, a new Diterpene acid from Juniperus Communis L. Acta Chem Scand. 1961;15:225-6.

59. Thomas AF. 1, 4-Dimethylcyclohex-3-enyl methyl ketone, a monoterpenoid with a novel skeleton. Helv Chim Acta. 1973;56:1800-2.

60. Yannai S. Dictionary of food compounds. With CD-ROM: additives, flavors, and ingredients. 2 ed. Chapman \& Hall/CRC: Boca Raton; 2004.

61. Teresa JdP, Barrero AF, Feliciano AS, Bellido IS. Anales de Quim. 1977:73:568.

62. Little CHA, Andrew DM, Silk PJ, Strunz GM. Identification of cytokinins zeatin and zeatin riboside in Abies Balsamea. Phytochemistry. 1979;18:1219-20. 
63. Williams AH. Dihydrochalcones; their occurrence and use as indicators in chemical plant taxonomy. Nature. 1964;202:824-5.

64. Wilkins CK, Bohm BA. Can J Bot 1976;54:2133.

65. Braekman JC, Nyembo L, Bourdoux P, Kahindo N, Hootele C. Distribution des alcaloides dans le genre Lycopodium. Phytochemistry. 1974;13:2519-28.

66. Manners GD, Swan EP. Stilbenes in the barks of five canadian Picea species. Phytochemistry. 1971;10:607-10.

67. Nozzolillo C, Isabelle P, Andersen OM, Abou-Zaid M. Anthocyanins of jack pine (Pinus Banksiana) seedlings. Can J Bot. 2002;80:796-801.

68. Rowe JW, Bower CL, Wagner ER. Extractives of jack pine bark: occurrence of cis- and trans-pinosylvin dimethyl ether and ferulic acid esters. Phytochemistry. 1969:8:235-41.

69. Vermes B, Chari VM, Wagner H. Structure elucidation and synthesis of Flavonol Acylglycosides. III.. The synthesis of tiliroside. Helv Chim Acta. 1981:64:1964-7.

70. Farkas L, Vermes B, Nógrádi M. Synthese von Flavonoidbis(glycosiden), V. Die Synthese sämtlicher bekannter natürlicher Quercetinbis(glucoside). Chem Ber. 1974;107:1518-25.

71. Abou-zaid MM, Nozzolillo C. Flavonol glycosides from needles of Pinus Banksiana. Biochem Syst Ecol. 1991;19:237-40.

72. Bower CL, Rowe JW. Extractives of jack pine bark: occurrence of (+)-13epimanoyl oxide and related labdane diterpenes. Phytochemistry. 1967:6:151-3.

73. Carman R, Duffield A. (+)\&\#945;-Bisabolol and (+)-Anymol. A Repetition of the Synthesis From the Limonene 8,9-Epoxides. Aust J Chem 1989;42:2035-2039.

74. Tanaka H, Ichino K, Ito K. Dihydrochalcones from lindera umbellata. Phytochemistry. 1984;23:1198-9.

75. Hillis WE, Orman HR. The extractives of New Zealand Nothofagus species. J Linn Soc Bot. 1962;58:175-84.

76. Harborne JB, Williams CA. Leaf survey of flavonoids and simple phenols in the genus rhododendron. Phytochemistry. 1971;10:2727-44.

77. Hörhammer L, Wagner H, Reinhardt H. Isolierung des Bis-(5,7,4'-Trihydroxy)-flavons "Amentoflavon" aus der Rinde vonViburnum prunifolium L. (Amerikan. Schneeball). Sci Nat. 1965;52:161.

78. Terahara N, Takeda Y, Nesumi A, Honda T. Anthocyanins from red flower tea (Benibana-cha), Camellia Sinensis. Phytochemistry. 2001;56:359-61.

79. Kolodziej $\mathrm{H}$. The first natural biflavonoid with flavanol and dihydroflavonol constituent units coupled at the B-ring. J Chem Soc Chem Commun. 1987; doi:10.1039/C39870000205

80. Emiko E-F, G-i N, Nishioka I, Hayashi K. Isolation and structures of Procyanidins (condensed tannins) from Rhaphiolepis Umbellata. Agric Biol Chem. 1986;50

81. Hsu F, Nonaka G, Nishioka I. Tannins and related compounds. XXXI. Isolation and characterization of Proanthocyanidins in Kandelia candel (L.) DRUCE. Chem Pharm Bull (Tokyo). 1985;33:3142-52.

82. Niemann GJ, Baas WJ. Phenolics from Larix needles, 14: Flavonoids and phenolic glucosides and ester of L-decidua [larch]. Z Naturforsch. 1978; Section c, eBiosciences:33.

83. Rodewald WJ, Grynkiewicz G. Lycopodium alkaloids, part VII. The alkaloids of lycopodium clavatum. Rocz Chem. 1977:51:1271-5.

84. Harborne JB, Baxter H. The handbook of the natural flavonoids. 2nd ed. Chichester et New York: Wiley; 1999.

85. Van Noorden CJ. The history of Z-VAD-FMK, a tool for understanding the significance of caspase inhibition. Acta Histochem. 2001;103:241-51.

86. Eid HM, Haddad PS. Mechanisms of action of indigenous antidiabetic plants from the boreal Forest of northeastern Canada. Advances in Endocrinology. 2014;2014:11.

87. Dannenbaum D, Kuzmina E, Lejeune P, Torrie J, Gangbe M. Prevalence of diabetes and diabetes-related complications in first nations communities in northern Quebec (Eeyou Istchee), Canada. Can J Diabetes. 2008;32:46-52.

88. Alnemri ES, Livingston DJ, Nicholson DW, Salvesen G, Thornberry NA, Wong WW, et al. Human ICE/CED-3 protease nomenclature. Cell. 1996;87:171.

89. Lozano GM, Bejarano I, Espino J, Gonzalez D, Ortiz A, Garcia JF, et al. Relationship between caspase activity and apoptotic markers in human sperm in response to hydrogen peroxide and progesterone. J Reprod Dev. 2009;55:615-21.

90. Degterev A, Boyce M, Yuan J. A decade of caspases. Oncogene. 2003;22:8543-67.

91. Lopez-Caamal F, Middleton RH, Huber HJ. Equilibria and stability of a class of positive feedback loops. J Math Biol. 2014;68:609-45.
92. Hengartner MO. The biochemistry of apoptosis. Nature. 2000;407:770-6.

93. Cullen SP, Martin SJ. Caspase activation pathways: some recent progress. Cell Death Differ. 2009;16:935-8.

94. Rapinski M, Musallam L, Arnason JT, Haddad P, Cuerrier A. Adipogenic activity of wild populations of Rhododendron Groenlandicum, a medicina shrub from the James Bay Cree traditional pharmacopeia. Evid Based Complement Alternat Med. 2015;2015:7.

95. Li S, Brault A, Sanchez Villavicencio M, Haddad PS. Rhododendron Groenlandicum (Labrador tea), an antidiabetic plant from the traditional pharmacopoeia of the Canadian eastern James Bay Cree, improves renal integrity in the diet-induced obese mouse model. Pharm Biol. 2016; doi:10.3109/13880209.2015.1137953.

96. Ouchfoun M, Eid HM, Musallam L, Brault A, Li S, Vallerand D, et al. Labrador tea (Rhododendron Groenlandicum) attenuates insulin resistance in a dietinduced obesity mouse model. Eur J Nutr. 2016:55:941-54.

97. Martineau LC, Adeyiwola-Spoor DC, Vallerand D, Afshar A, Arnason JT, Haddad PS. Enhancement of muscle cell glucose uptake by medicinal plant species of Canada's native populations is mediated by a common, metformin-like mechanism. J Ethnopharmacol. 2010;127:396-406.

\section{Submit your next manuscript to BioMed Central and we will help you at every step:}

- We accept pre-submission inquiries

- Our selector tool helps you to find the most relevant journal

- We provide round the clock customer support

- Convenient online submission

- Thorough peer review

- Inclusion in PubMed and all major indexing services

- Maximum visibility for your research

Submit your manuscript at www.biomedcentral.com/submit 